\title{
Assessing the Harms of Cannabis Cultivation in Belgium
}

\author{
Letizia Paoli (University of Leuven) \\ \& Tom Decorte (Ghent University)*
}

* Based on work with Loes Kersten, Julie Heyde and Evelien van Dun funded by Belgian Science Policy 


\section{Cannabis: shift in cultivation, shift in policy?}

- Since the 1980 s domestic production of cannabis herb (i.e., marijuana) has risen in most consumer countries

- Shift was particularly far-reaching in The Netherlands and has later invested neighbors

- Large-scale cannabis cultivation is said to produce large revenues for organized crime groups and to be source of violence and corruption

- Law enforcement efforts primarily aim to reduce availability but also to reduce organized crime profits and harms

- Cannabis is only drug for which thorough policy change is possible in mid-term

How does cannabis cultivation in Belgium take place?

Which harms are associated with it and what are their severity, incidence and causes? 


\section{Outline}

- Project aims, methods and samples

- The harm assessment framework (Greenfield \& Paoli, 2013)

- Identifying the harms associated with cannabis cultivation and its accompanying activities

- Assessing the severity and incidence of the harms and establishing their causes

- Concluding remarks 


\section{Outline}

Project aims, methods and samples

- The harm assessment framework (Greenfield \& Paoli, 2013)

- Constructing the business model of cannabis cultivation and identifying the related harms

- Assessing the severity and incidence of the harms and establishing their causes

- Concluding remarks 


\section{Project aims}

1. To describe the organization of cannabis production in Belgium

2. To create typologies of different types of cannabis producers in Belgium and identify their modi operandi and aims

3. To assess the market significance of different types of cannabis producers in Belgium (i.e. market segments)

4. To estimate the harms associated with different types of producers and

5. To evaluate the impact of the Belgian drug policy strategies on them 


\section{Methods and samples}

- Research design combines quantitative and qualitative methods

- Ghent team was responsible for internet survey, part of GCCRC

- 1,293 valid surveys from whole of Belgium: age 18-81, mostly males (90.9\%), mostly small-scale $(73.4 \%<5$ plants; $98.3 \%<49$ plants)

- Leuven team was responsible for qualitative data collection focusing on large-scale cultivators

- 20 interviews with imprisoned cultivators: aged 24-63, all males, 17 Belgian, 3 Dutch

- 28 interviews with experts, mostly but not exclusively from law enforcement

- Analysis of 34 criminal cases opened in 2005-2011: 1-46 suspects per case, aged 18-69, mostly males (85.5\%), Dutch and Belgian, all large-scale

- Data have obvious limitations, which are only partially alleviated by triangulation 


\section{Outline}

- Project aims, methods and samples

$>$ The harm assessment framework (Greenfield and Paoli, 2013)

- Constructing the business model of cannabis cultivation and identifying the related harms

- Assessing the severity and incidence of the harms and establishing their causes

- Concluding remarks 


\section{Harm assessment framework}

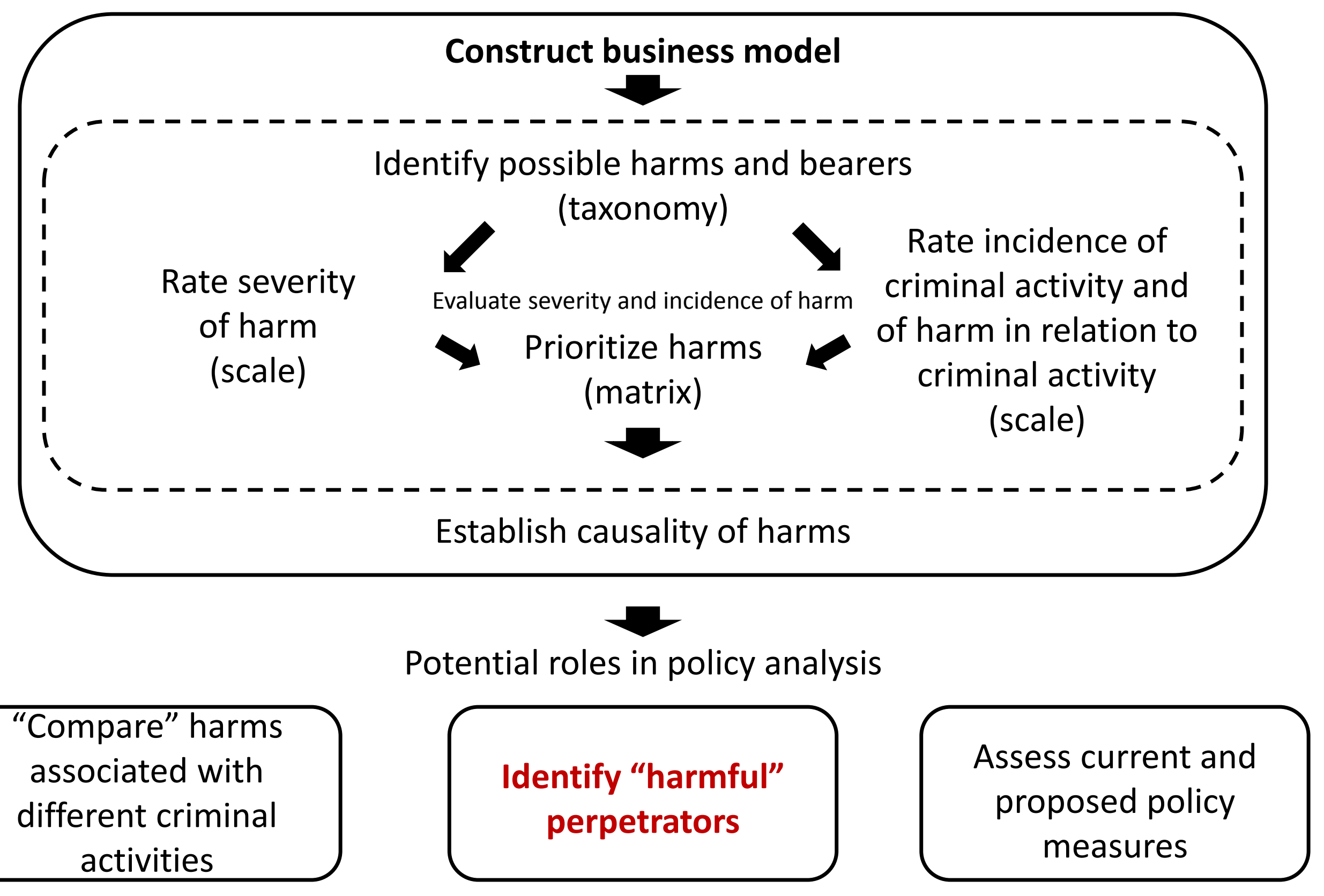




\section{Harm assessment framework}

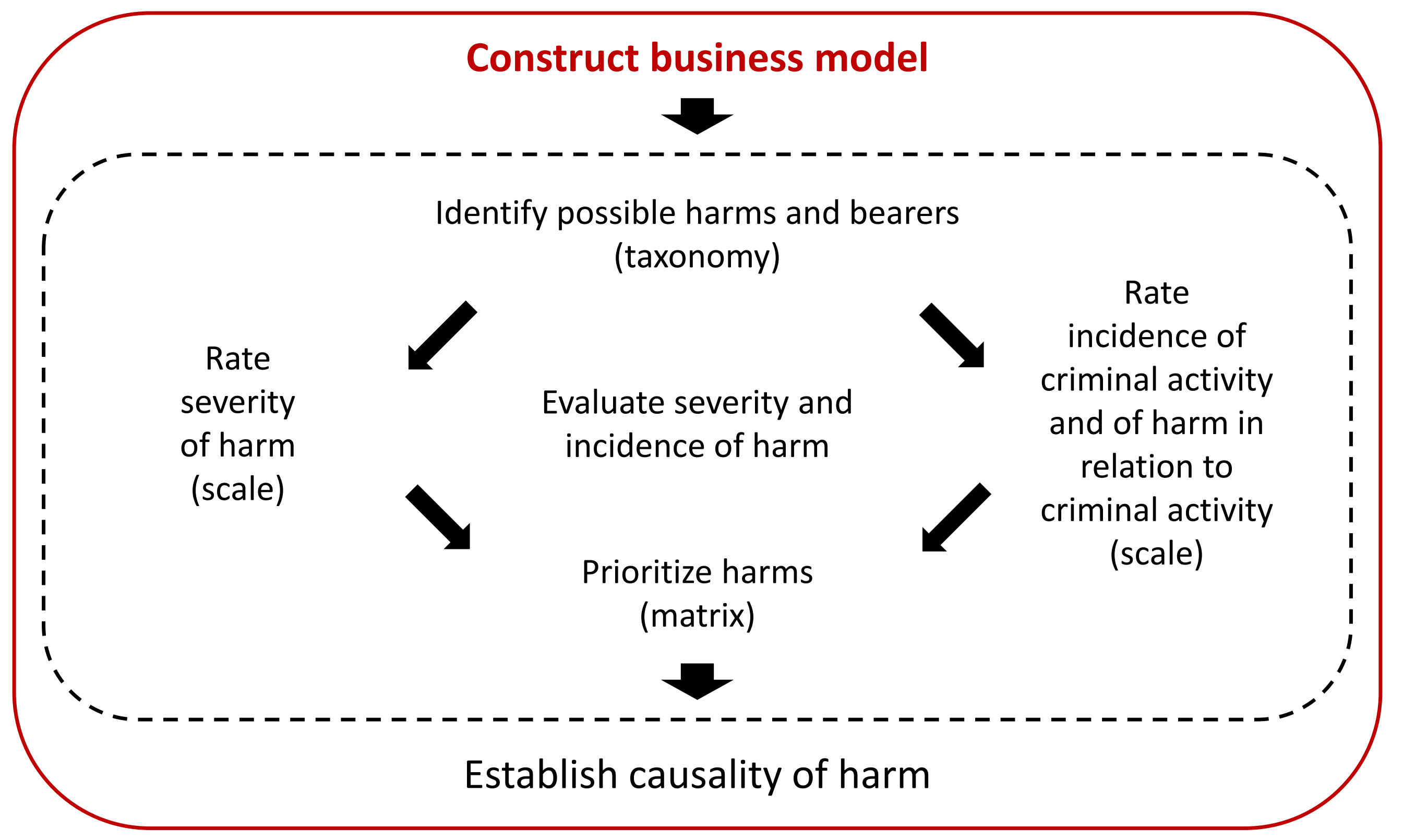




\section{Harm assessment framework}

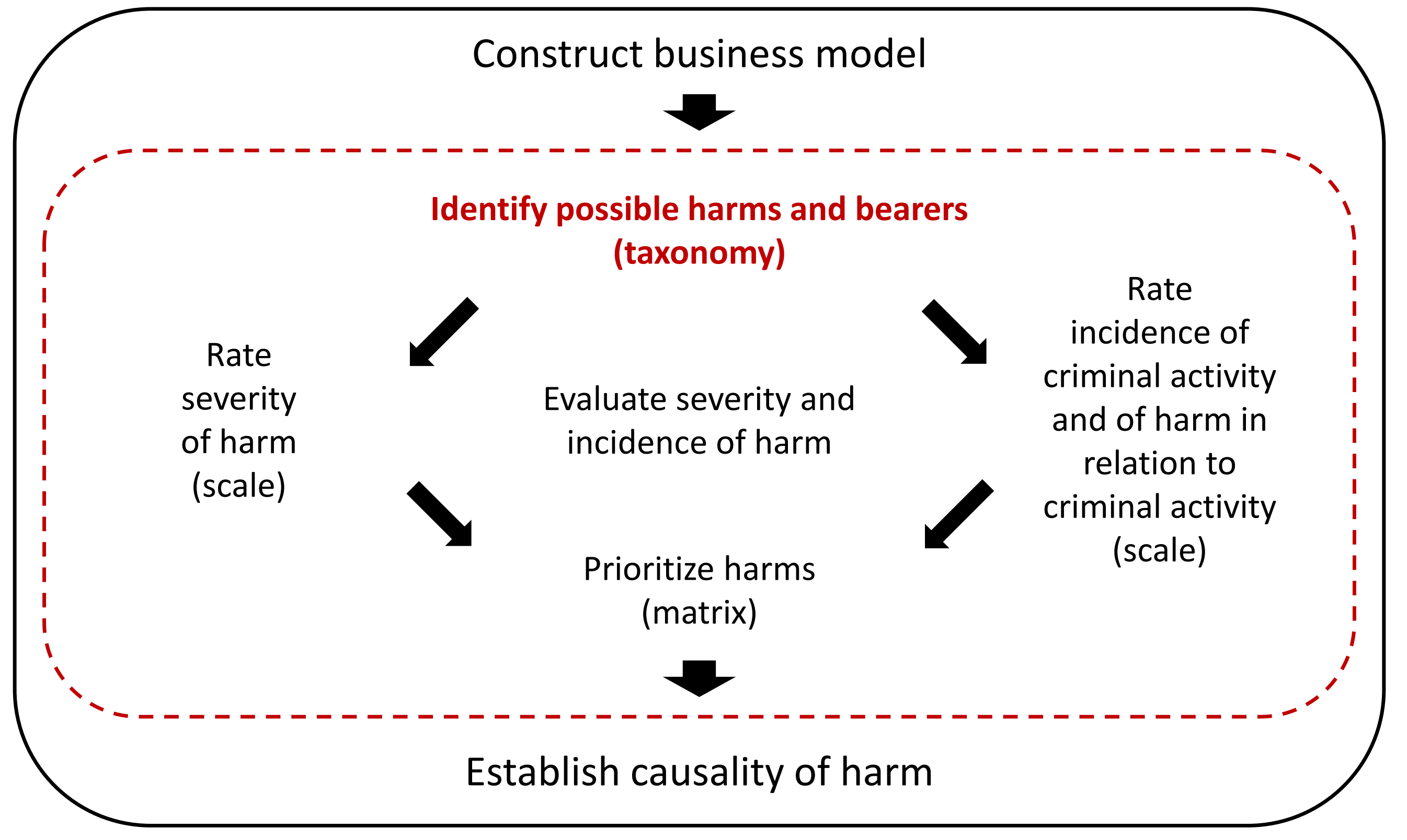




\section{Taxonomy delineates type \& bearers}

\begin{tabular}{lcccc}
\hline & \multicolumn{4}{c}{ BEARER OF HARM } \\
\cline { 2 - 5 } & Individuals & $\begin{array}{c}\text { Private- } \\
\text { Sector } \\
\text { Entities }\end{array}$ & $\begin{array}{c}\text { Government } \\
\text { Entities }\end{array}$ & Environment \\
\hline TYPE OF HARM & $\mathrm{X}^{*}$ & $\mathrm{X}^{* *}$ & $\mathrm{X}^{* *}$ & $\mathrm{X}$ \\
Functional integrity & $\mathrm{X}$ & $\mathrm{X}$ & $\mathrm{X}$ & $\mathrm{n} / \mathrm{a}$ \\
Material interest & $\mathrm{X}$ & $\mathrm{X}$ & $\mathrm{X}$ & $\mathrm{n} / \mathrm{a}$ \\
Reputation & $\mathrm{X}$ & $\mathrm{X}$ & $\mathrm{X}$ & $\mathrm{n} / \mathrm{a}$ \\
\hline Privacy & & & & \\
\hline
\end{tabular}

Source: authors drawing from von Hirsch and Jareborg (1991) and others.

Notes: $\mathrm{X}=$ applicable; $\mathrm{n} / \mathrm{a}=$ not applicable;

* Functional integrity = Physical and psychological integrity;

** Functional integrity = Operational integrity;

$* * *$ Functional integrity $=$ Physical, operational, and aesthetic integrity 


\section{Harm assessment framework}

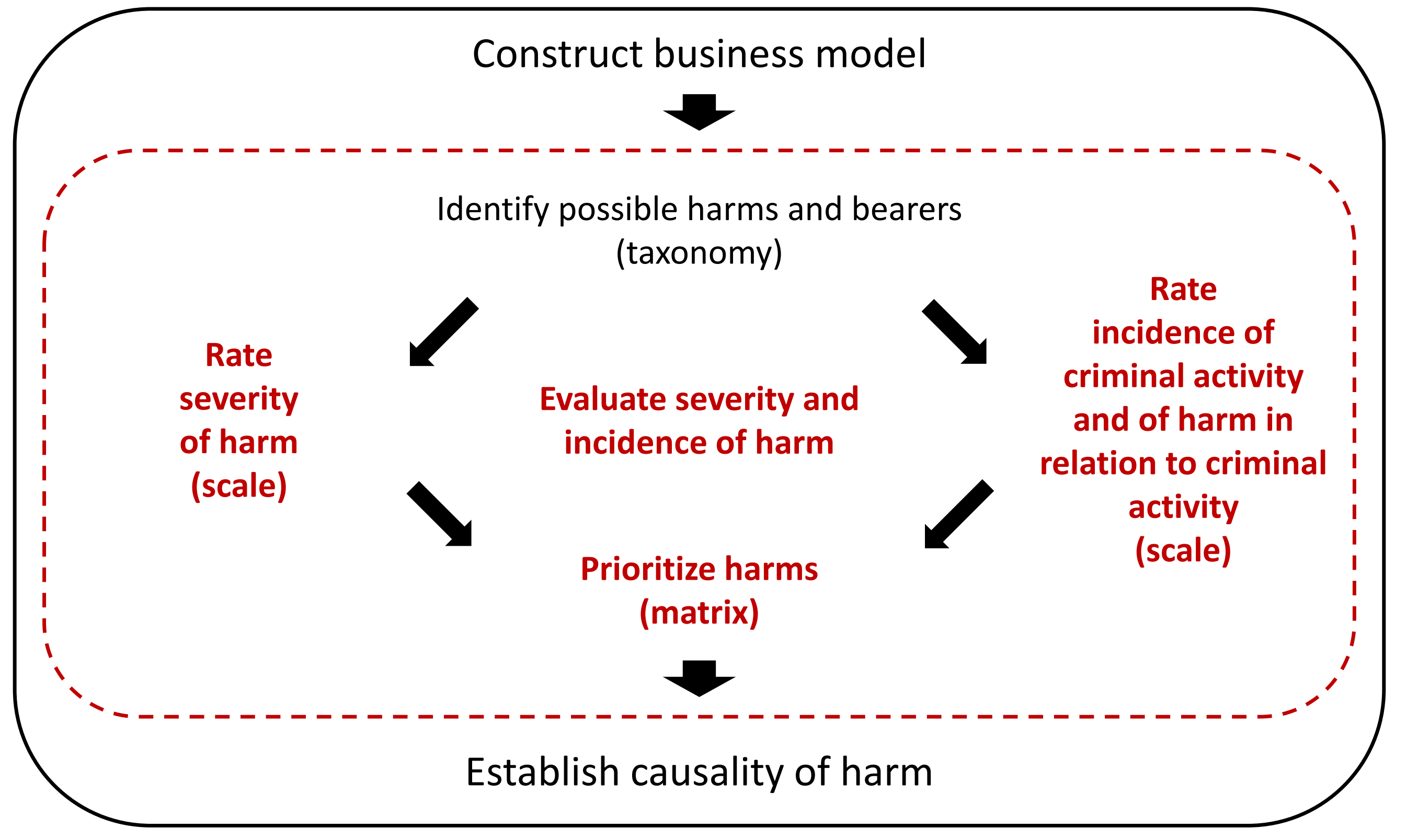




\section{Common benchmarks gauge severity}

\begin{tabular}{lll}
\hline $\begin{array}{l}\text { SEVERITY } \\
\text { RATING }\end{array}$ & $\begin{array}{l}\text { Level of individual's living standard at } \\
\text { which damage occurs }\end{array}$ & $\begin{array}{l}\text { Level of entity's mission capability at } \\
\text { which damage occurs }\end{array}$ \\
\hline Catastrophic & $\begin{array}{l}1^{\circ} \text { : Subsistence, consisting of survival, } \\
\text { but with maintenance of no more than } \\
\text { elementary capacities to function }\end{array}$ & $\begin{array}{l}1^{\circ}: \text { Viability, consisting of survival, } \\
\text { but with maintenance of no more than } \\
\text { elementary capacities to function }\end{array}$ \\
Grave & $2^{\circ}:$ Minimal standard of living & $2^{\circ}:$ Minimal mission capabilities \\
Serious & $3^{\circ}:$ Adequate standard of living & $3^{\circ}:$ Adequate mission capabilities \\
Moderate & $4^{\circ}:$ Enhanced standard of living & $4^{\circ}:$ Enhanced mission capabilities \\
Marginal & Marginal or no effect at any level & Marginal or no effect at any level \\
\hline
\end{tabular}

- Drawn from von Hirsch and Jareborg's (1991) living-standard approach

- Extended to other bearers by analogy, e.g., from living standard to capability to achieve mission for private-sector and government entities

- Used to assess effects of intrusions upon different interests (functional integrity, material interest, reputation, and privacy), levels of analysis require specification 


\section{Incidence provides grounding for prioritizing harms}

Matrix of severity, incidence, and priorities

\begin{tabular}{lccccc}
\hline SEVERITY & \multicolumn{5}{c}{ INCIDENCE } \\
\hline & Always & Persistently & Occasionally & Seldom & Rarely \\
\hline Catastrophic & $\mathrm{H}$ & $\mathrm{H}$ & $\mathrm{H}$ & $\mathrm{H} / \mathrm{M}$ & $\mathrm{M} / \mathrm{H}$ \\
Grave & $\mathrm{H}$ & $\mathrm{H}$ & $\mathrm{H} / \mathrm{M}$ & $\mathrm{M} / \mathrm{H}$ & $\mathrm{M}$ \\
Serious & $\mathrm{H}$ & $\mathrm{H} / \mathrm{M}$ & $\mathrm{M} / \mathrm{H}$ & $\mathrm{M}$ & $\mathrm{L}$ \\
Moderate & $\mathrm{H} / \mathrm{M}$ & $\mathrm{M} / \mathrm{H}$ & $\mathrm{M}$ & $\mathrm{L}$ & $\mathrm{L}$ \\
Marginal & $\mathrm{M} / \mathrm{H}$ & $\mathrm{M}$ & $\mathrm{L}$ & $\mathrm{L}$ & $\mathrm{L}$ \\
\hline
\end{tabular}

Source: authors based on Greenfield and Camm, 2005.

Notes: $\mathrm{H}=$ Highest priority; $\mathrm{M}=$ Medium priority; $\mathrm{L}=$ Lowest priority; we use "non applicable" for harms that are irrelevant in a particular context.

Matrix offers preliminary basis for addressing incommensurability, using quantitative and qualitative data 


\section{Harm assessment framework}

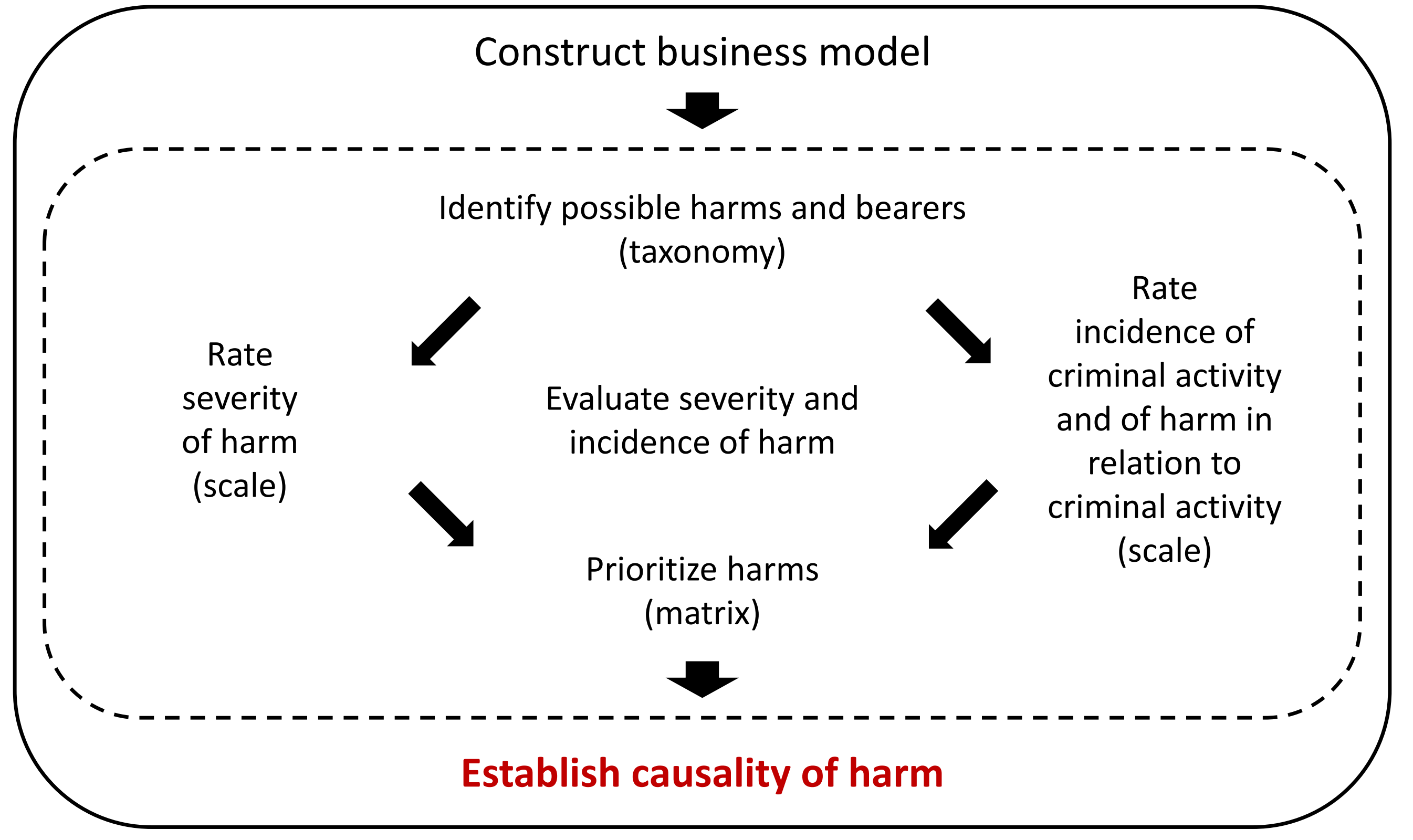




\section{Outline}

- Project aims, methods and samples

- The harm assessment framework (Greenfield \& Paoli, 2013)

$>$ Constructing the business model of cannabis cultivation and identifying the related harms

- Assessing the severity and incidence of the harms and establishing their causes

- Concluding remarks 


\section{Working through harm assessment process}

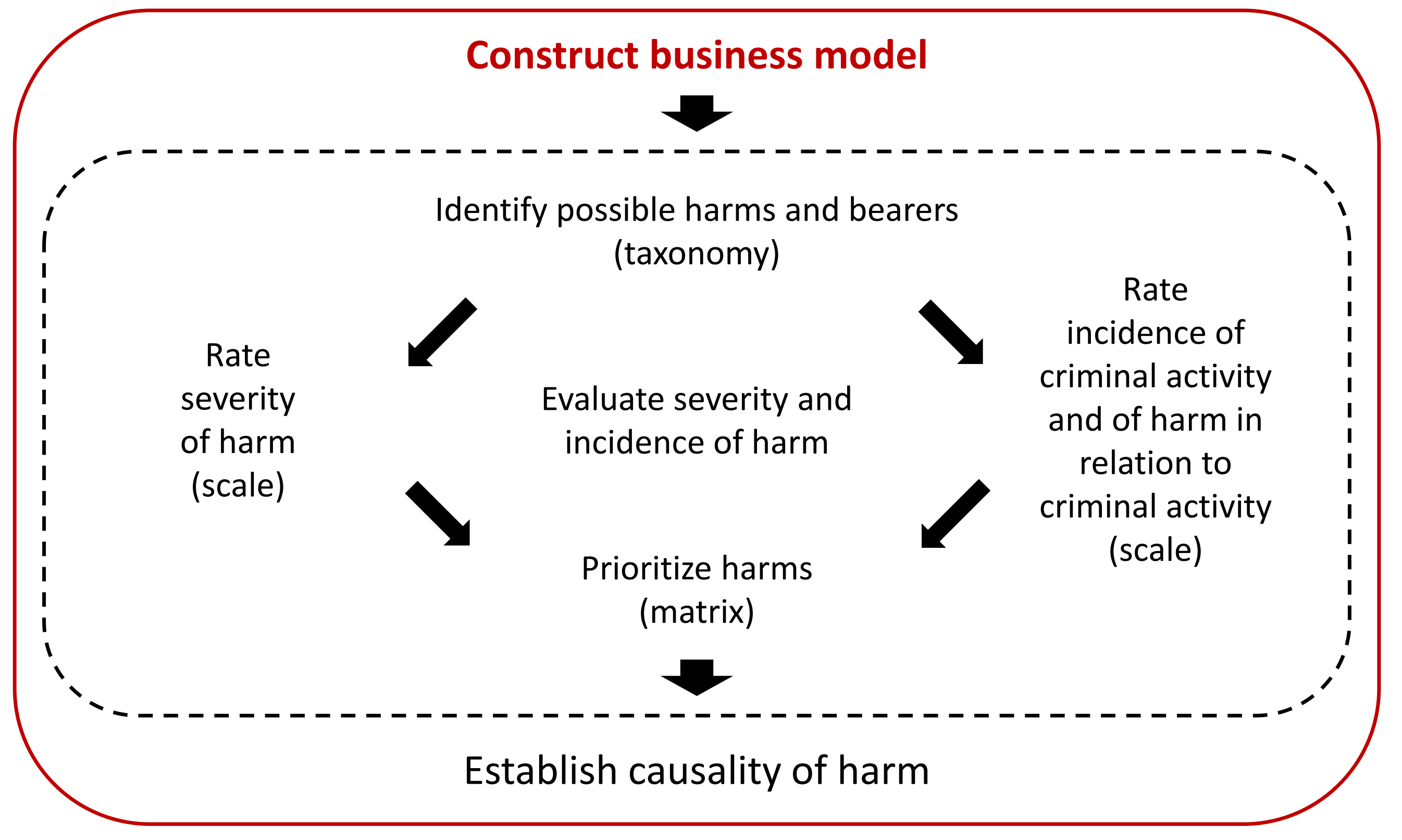




\section{The business model of cannabis cultivation}

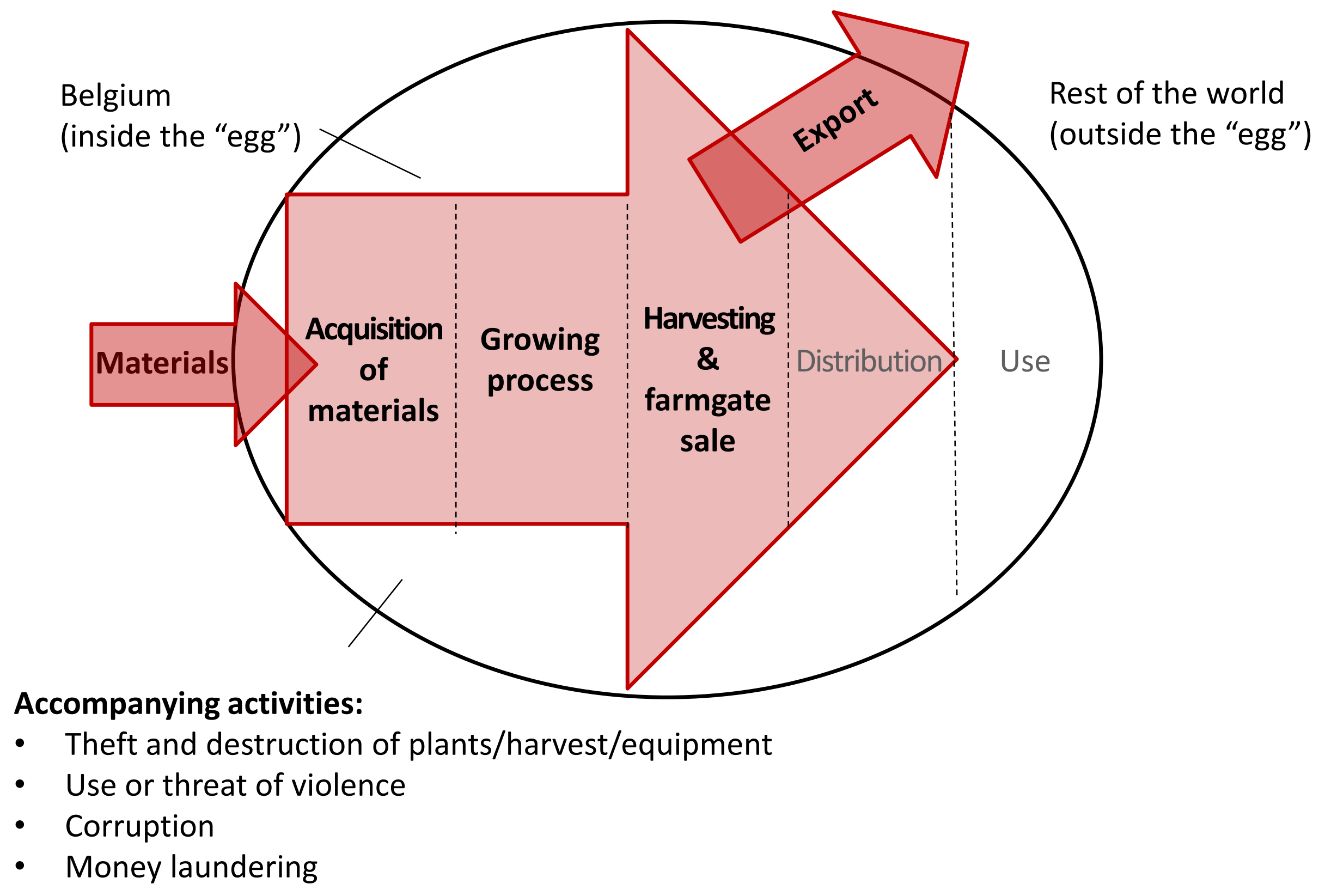




\section{The growing process and related harms}

- Most survey respondents (74.1\%) cultivate on/in their own property, outdoor and indoor, and hence cause no harm to others

- Interviewed large-scale cultivators grow indoor, in rented properties, occasionally buying owners off or using false IDs

- Electricity theft is source of largest harm in this phase

- $7 \%$ of survey respondents $(18.4 \%>20$ plants, $n=13)$ and almost all interviewed cultivators admit theft

- Harms assessed in $€ 4,000$ to $€ 98,000$ per plantation in criminal cases

- According to Eandis, $80 \%$ of recorded thefts are cannabis-related; 1,040 cases in 2003-2010; average harm is $€ 22,018$ per case

- Electricity theft also occasionally sets up fires

- Harms sometimes result also from the destruction of property and water overflow

- Survey provides no data on this, but according to police 3 to 5 plantations were discovered each year in 2006-11 due to water damages 


\section{Harvesting and sale and related harms}

- Small-scale cultivators (<20 plants) harvest plant themselves and produce no harm

- Very large-scale cultivators sometimes recruit "cutting teams"

- In six criminal cases Eastern Europeans were recruited, were paid regular salaries but also "surveilled"

- Some interviewed cultivators report good treatment of cutters but others and experts suggest exploitation

- E.g., hard work, no pay, transport in shuttered buses

- Only $8.1 \%$ of survey respondents (36.1\% > plants) but all cultivators interviewed and charged in criminal cases are interested in monetary profits

- Some interviewed cultivators admit considerable earnings

- "Farmgate" price is around $€ 3.500$ per $\mathrm{Kg}$

- 250 plants deliver at least $30 \mathrm{Kg}$ per harvest, thus can be sold at $€ 100,000$ 


\section{Theft and destruction of plants/harvest/equipment}

- Theft and destruction of plants/harvest/equipment may occur to all cultivators but especially to those cultivating more than 20 plants

- $13.7 \%$ of survey respondents $(17.7 \%>20$ plants $)$ admit having been involved in theft of plants, $5.6 \%$ (18.2\% > 20 plants) in theft of harvest, $1.8 \%$ in theft of equipment $(9.4 \%>20$ plants) and $12.3 \%$ in destruction of plants $(30.3 \%>20$ plants)

- 4 interviewed cultivators and 4 criminal cases also report theft of cannabis

- These activities often lead to violence but in our framework, they produce per se no harm, as they involve illegal property

- Experts speak of booby traps to discourage theft but other sources provide no supporting evidence 


\section{Use or threat of violence and related harms}

- Only $6.8 \%$ of survey respondents have direct experience of verbal conflicts, only $1.5 \%$ of actual violence

- Those cultivating more than 20 plants are more frequently involved: $12.9 \%$ in verbal conflicts, $6.5 \%$ in physical conflicts

- Some physical conflicts reported have had serious consequences

- Eight injuries, one permanent injury, one death

- Counterparts are relatives, friends but also customers/suppliers or thieves

- Other sources also report little violence

- Only three out of 20 interviewed cultivators have direct experience of physical violence

- Consequences can be serious,: in one case a paralysis

- Counterparts are mostly unknown thieves

- Two out of 34 criminal cases report a kidnapping and two shoot-outs, seven others threats

- Experts report no violence

- Violence is probably underreported in criminal justice sources 


\section{Corruption and related harms}

- According to all sources there is very limited, low-level governmental corruption

- 64 survey respondents report contacts with police officers, 20 with other officials

- Two interviewed cultivators report contacts with law enforcement officers

- Criminal cases mention small (suspected) favors

- It is unclear if anyone was really bribed

- Private-sector representatives are more frequently involved as facilitators

- $15.6 \%$ of survey respondents report receiving help from (Dutch) grow- and coffeeshops, $10 \%$ from electricians or lawyers

- Those cultivating more than 20 plants report more frequently help from electricians and lawyers (25.8\%)

- Interviewed cultivators and criminal cases also highlight role of growshops and electricians but also report favors from real estate agents and involvement of car rentals and other logistics enterprises

- Some of these facilitators work independently, some harm their companies 


\section{Money laundering and related harms}

- According to all sources, earnings are primarily used to buy luxury goods and support lush lifestyle but are also reinvested in cannabis cultivation and, more rarely, in other illegal activities

- Earnings suggest that crime pays, thus tainting government's reputation

- Private-sector facilitators are sometimes used to launder money

- Survey respondents admitted receiving help from lawyers (33), notaries (9), bank officials (8), accountants (5), insurance companies officials and tax advisors (2 each)

- A few criminal cases provide evidence of "sophisticated" laundering techniques 


\section{Working through harm assessment process}

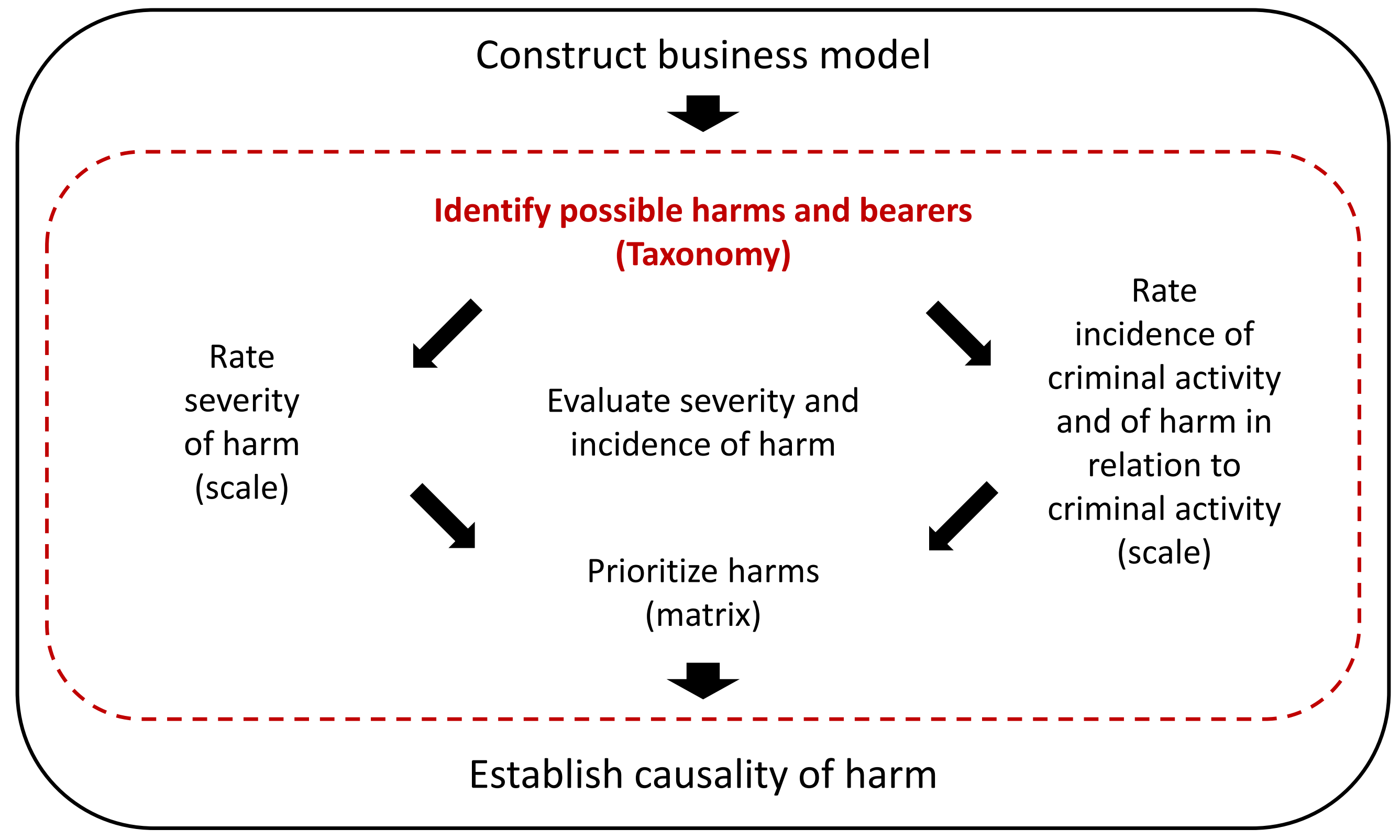




\title{
Possible harms touch upon many interests
}

\author{
Growing Harvesting Comuption Violence Money \\ $\&$ sale laundering \\ Bearers
}

HARMS TO INDIVIDUALS, specifically to their:

\section{Functional integrity}

Loss of life $\mathrm{n} / \mathrm{a}$

$\mathrm{n} / \mathrm{a}$

$\mathrm{n} / \mathrm{a}$

$X$

$\mathrm{n} / \mathrm{a}$

- Cultivators, their relatives, friends,

Other: physical \&

psychological

$n / a \quad n / a \quad n \quad n / a$

Only

psychological

$\mathrm{n} / \mathrm{a}$

$X$

$\mathrm{n} / \mathrm{a}$

$X$

$\mathrm{n} / \mathrm{a}$

$\mathrm{x} \quad \mathrm{n} / \mathrm{a}$

$\mathrm{n} / \mathrm{a}$

$x$

$\mathrm{n} / \mathrm{a}$

$\mathrm{n} / \mathrm{a} \quad \mathrm{n} / \mathrm{a}$

X
suppliers/customers and thieves, if targeted by use of violence

- All persons targeted by use of violence

- All persons targeted by threats

- Member of cutting teams, if intimidated

- Ancillary to functional harms, for those targeted by use or threat of violence

$n / a$

interest

$x^{2}+x^{2}$

$$
\text { Re }
$$

Privacy

$\mathrm{n} / \mathrm{a}$

$x \quad n / a$

X

$x$

$\mathrm{n} / \mathrm{a}$

$\mathrm{X}$

$\mathrm{n} / \mathrm{a}$

- Owners of property, if this is damaged

- All persons targeted by use or threat of violence

- Owners of property, if this is misused w/o their knowledge

- Same two categories as for reputation

- Member of cutting teams, if controlled 


\begin{tabular}{|c|c|c|c|c|c|c|}
\hline & Growing & $\begin{array}{l}\text { Harvesting } \\
\text { \& sale }\end{array}$ & Comuption & Violence & $\begin{array}{l}\text { Money } \\
\text { laundering }\end{array}$ & Bearers \\
\hline \multicolumn{7}{|c|}{ HARMS TO PRIVATE-SECTOR ENTITIES, specifically to their: } \\
\hline Functional integrity & $\mathrm{n} / \mathrm{a}$ & $\mathrm{n} / \mathrm{a}$ & $\mathrm{X}$ & $\mathrm{n} / \mathrm{a}$ & $\mathrm{X}$ & $\begin{array}{l}\text { - Specialized shops, electrical companies, farms } \\
\text { and law and logistics firms, if corrupt employees } \\
\text { misuse assets w/o their knowledge }\end{array}$ \\
\hline Material interest & $\mathrm{X}$ & $\mathrm{n} / \mathrm{a}$ & $\mathrm{X}$ & $\mathrm{n} / \mathrm{a}$ & $\mathrm{n} / \mathrm{a}$ & $\begin{array}{l}\text { - Ancillary to functional harms (property) } \\
\text { - Electrical companies, if electricity is stolen } \\
\text { - Owners of property, if this is damaged }\end{array}$ \\
\hline Reputation & $\mathrm{X}$ & $\mathrm{n} / \mathrm{a}$ & $\mathrm{X}$ & $\mathrm{n} / \mathrm{a}$ & $\mathrm{X}$ & $\begin{array}{l}\text { - Specialized shops, electrical companies, farms } \\
\text { and law and logistics firms, if corrupt employees } \\
\text { misuse assets w/o their knowledge } \\
\text { - Owners of property, if this is damaged }\end{array}$ \\
\hline "Privacy" & $\mathrm{X}$ & $\mathrm{n} / \mathrm{a}$ & $\mathrm{X}$ & $\mathrm{n} / \mathrm{a}$ & $\mathrm{n} / \mathrm{a}$ & - Same two categories as for reputation \\
\hline \multicolumn{7}{|c|}{ HARMS TO GOVERNMENT, specifically to its: } \\
\hline Functional integrity & $\mathrm{n} / \mathrm{a}$ & $\mathrm{n} / \mathrm{a}$ & $\mathrm{X}$ & $\mathrm{n} / \mathrm{a}$ & $\mathrm{n} / \mathrm{a}$ & $\begin{array}{l}\text { - Government agencies, if representatives engage } \\
\text { in corrupt practices, incl. neglect of duties }\end{array}$ \\
\hline Material interest & $\mathrm{n} / \mathrm{a}$ & $\mathrm{n} / \mathrm{a}$ & $\mathrm{x}$ & $\mathrm{x}$ & $\mathrm{n} / \mathrm{a}$ & $\begin{array}{l}\text { - Ancillary to functional harms (health) } \\
\text { - Wages associated with neglect of duties }\end{array}$ \\
\hline \multirow{2}{*}{ Reputation } & $\mathrm{n} / \mathrm{a}$ & $\mathrm{n} / \mathrm{a}$ & $\mathrm{X}$ & $\mathrm{n} / \mathrm{a}$ & $\mathrm{n} / \mathrm{a}$ & $\begin{array}{l}\text { - Government agencies, if representatives engage } \\
\text { in corrupt practices, incl. neglect of duties }\end{array}$ \\
\hline & $\mathrm{x}$ & $x$ & $\mathrm{X}$ & $x$ & $x$ & $\begin{array}{l}\text { - Government writ large, if it cannot enforce its } \\
\text { laws }\end{array}$ \\
\hline "Privacy" & $\mathrm{n} / \mathrm{a}$ & $\mathrm{n} / \mathrm{a}$ & $x$ & $\mathrm{n} / \mathrm{a}$ & $\mathrm{n} / \mathrm{a}$ & $\begin{array}{l}\text { - Government agencies, i.e., if } \\
\text { officials/representatives engage in corrupt } \\
\text { practices, incl. neglect of duties }\end{array}$ \\
\hline \multicolumn{7}{|c|}{ HARMS TO ENVIRONMENT, specifically to its: } \\
\hline Functional integrity & $\mathrm{n} / \mathrm{a}$ & $\mathrm{n} / \mathrm{a}$ & $\mathrm{n} / \mathrm{a}$ & $\mathrm{n} / \mathrm{a}$ & $\mathrm{n} / \mathrm{a}$ & \\
\hline
\end{tabular}




\section{Outline}

- Project aims, methods and samples

- The harm assessment framework (Greenfield \& Paoli, 2013)

- Identifying the harms associated with cannabis cultivation and its accompanying activities

$>$ Assessing the severity and incidence of the harms and establishing their causes

- Concluding remarks 


\section{Working through harm assessment process}

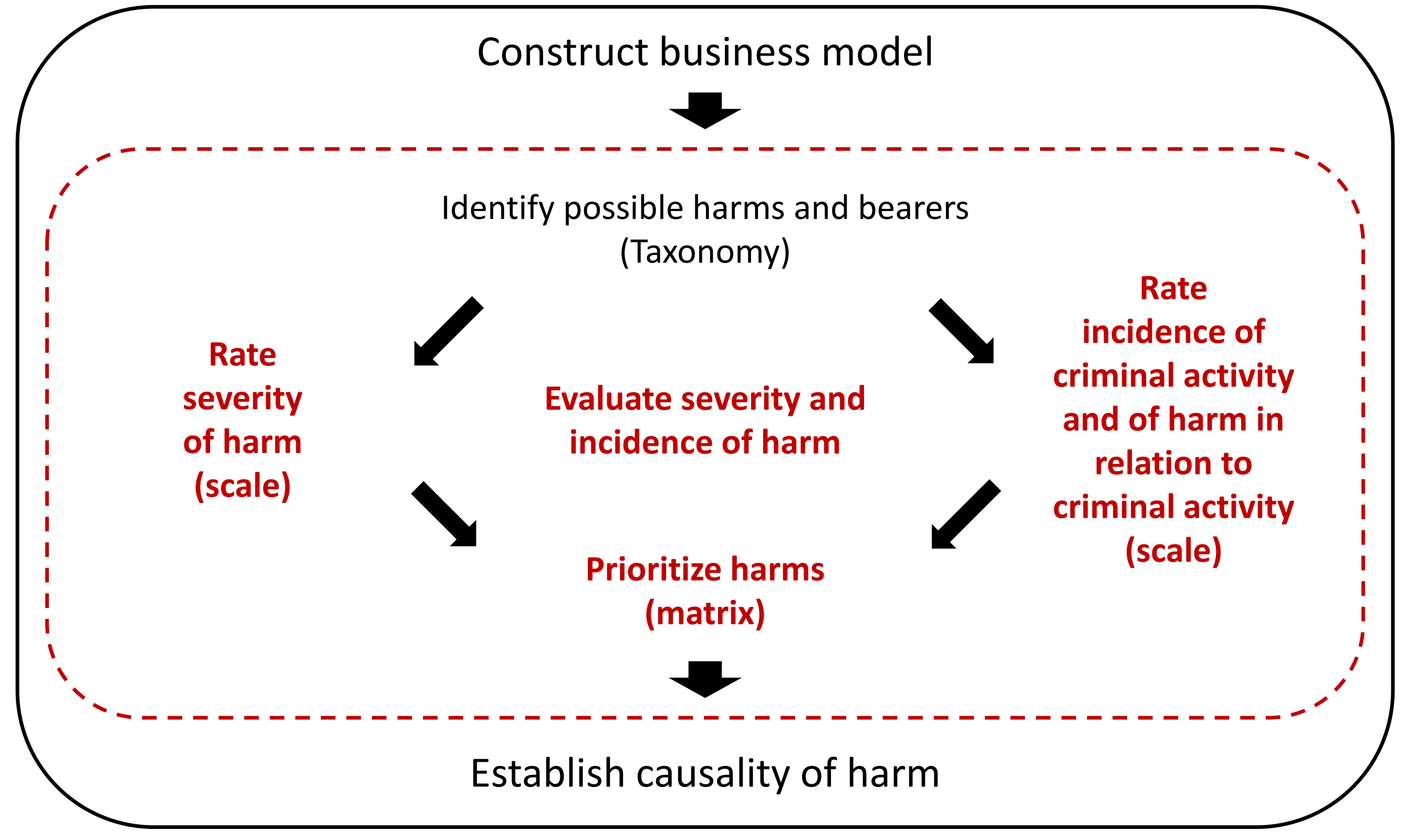




\section{Cannabis production occurs always}

- Sharp increase in number of plant seizures and detected "plantations" (> 2 plants) in Belgium since 2000

- From 73,334 plants and 35 plantations in 2003 to 337,955 plants and 1,069 plantations in 2011

Plantations detected by the Belgian Federal Police, by scale, 2007-2011

\begin{tabular}{lccccc}
\hline Year & $\mathbf{2 0 0 7}$ & $\mathbf{2 0 0 8}$ & $\mathbf{2 0 0 9}$ & $\mathbf{2 0 1 0}$ & $\mathbf{2 0 1 1}$ \\
\hline Micro scale: 2-5 plants & 66 & 136 & 134 & 209 & 190 \\
Mini scale: 6-49 plants & 130 & 219 & 226 & 313 & 376 \\
Small scale: 50-249 plants & 62 & 125 & 166 & 163 & 187 \\
Middle scale: 250-499 plants & 40 & 58 & 72 & 93 & 101 \\
Large scale: 500-999 plants & 44 & 63 & 65 & 106 & 119 \\
Industrial scale: >1000 plants & 51 & 45 & 66 & 86 & 88 \\
Seedling farms & 5 & 2 & 8 & 9 & 8 \\
Total & $\mathbf{3 9 8}$ & $\mathbf{6 4 8}$ & $\mathbf{7 3 7}$ & $\mathbf{9 7 9}$ & $\mathbf{1 0 6 9}$ \\
\hline
\end{tabular}

Source: Belgian Federal Police, 2012.

- At any moment cannabis is being cultivated in Belgium

- Belgian production feeds Belgian market and Dutch coffeeshops 


\section{Actual harms accrue to individuals*}

\begin{tabular}{|c|c|c|c|c|}
\hline & Severity & Incidence** & Priority & Activity \\
\hline \multicolumn{5}{|c|}{ HARMS TO INDIVIDUALS, specifically to their: } \\
\hline \multicolumn{5}{|l|}{ Functional integrity } \\
\hline Loss of life & Catastrophic & Rarely & $\mathrm{M} / \mathrm{H}_{\mathrm{i}}$ & Violence \\
\hline \multirow{4}{*}{$\begin{array}{r}\text { Other physical and } \\
\text { psychological }\end{array}$} & Grave & Rarely & $\mathbf{M}_{\mathbf{i}}$ & $\begin{array}{l}\text { Violence (i.e., assault causing permanent } \\
\text { damages) }\end{array}$ \\
\hline & Serious & Rarely & $\mathrm{L}_{\mathrm{i}}$ & Violence (i.e., assault and kidnapping) \\
\hline & Moderate & Rarely & $\mathrm{L}_{\mathrm{i}}$ & $"$ \\
\hline & Marginal & Rarely & $\mathrm{L}_{\mathrm{i}}$ & Violence (i.e., petty assault) \\
\hline \multirow{2}{*}{ Only psychological } & Marginal & Seldom & $\overrightarrow{L_{i}}$ & Violence threatened (i.e., intimidation) \\
\hline & Marginal & Rarely & $\mathrm{L}_{\mathrm{i}}$ & Harvesting, if cutting teams are intimidated \\
\hline
\end{tabular}

*Estimates exclude harms associated with cannabis distribution and use.

** Overall incidence, accounting for incidence of activities and of harms in relation to activities. 


\section{Actual harms accrue to individuals*}

\begin{tabular}{|c|c|c|c|c|}
\hline & Severity & Incidence** & Priority & Activity \\
\hline \multicolumn{5}{|c|}{ HARMS TO INDIVIDUALS, specifically to their: } \\
\hline \multirow{3}{*}{ Material interest } & Serious & $\begin{array}{l}\text { Seldom to } \\
\text { rarely }\end{array}$ & $M / L_{i}$ & $\begin{array}{l}\text { Growing, if rented properties are seriously } \\
\text { damaged (e.g., fire) }\end{array}$ \\
\hline & Moderate & Occasionally & $M_{i}$ & $\begin{array}{l}\text { Growing, if rented properties are damaged } \\
\text { (e.g., waterflow) }\end{array}$ \\
\hline & Marginal & Persistently & $\mathbf{M}_{\mathbf{i}}$ & $\begin{array}{l}\text { Growing, if rented properties are damaged } \\
\text { (e.g., holes in walls) }\end{array}$ \\
\hline \multirow{3}{*}{ Reputation } & Moderate & Rarely & $\mathrm{L}_{\mathrm{i}}$ & Violence (i.e., all forms of assault) \\
\hline & Marginal & Seldom & $\mathrm{L}_{\mathrm{i}}$ & Violence threatened (i.e., intimidation) \\
\hline & Marginal & Seldom & $L_{i}$ & $\begin{array}{l}\text { Growing, if rented properties are misused w/o } \\
\text { the owner's knowledge }\end{array}$ \\
\hline \multirow{3}{*}{ Privacy } & Moderate & Rarely & $L_{i}$ & Violence (i.e., assault and kidnapping) \\
\hline & Marginal & Rarely & $\mathrm{L}_{\mathrm{i}}$ & $\begin{array}{l}\text { Growing, if rented properties are misused w/o } \\
\text { the owner's knowledge }\end{array}$ \\
\hline & Marginal & Rarely & $\mathrm{L}_{\mathrm{i}}$ & Harvesting, if cutting teams are controlled \\
\hline
\end{tabular}

* Estimates exclude harms associated with cannabis distribution and use.

** Overall incidence, accounting for incidence of activities and of harms in relation to activities. 


\section{Actual harms also accrue to others*}

Severity Incidence** Priority

Activity

\begin{tabular}{|c|c|c|c|c|}
\hline \multicolumn{5}{|c|}{ HARMS TO PRIVATE-SECTOR ENTITIES, specifically to their: } \\
\hline $\begin{array}{l}\text { Functional } \\
\text { integrity }\end{array}$ & Marginal & Seldom & $\mathrm{L}_{\mathrm{ps}}$ & Corruption and money laundering \\
\hline Reputation & Marginal & Seldom & $\mathrm{L}_{\mathrm{ps}}$ & Corruption and money laundering \\
\hline "Privacy" & Marginal & Seldom & $\mathrm{L}_{p s}$ & Corruption and money laundering \\
\hline \multicolumn{5}{|c|}{ HARMS TO GOVERNMENT, specifically to its: } \\
\hline $\begin{array}{l}\text { Functional } \\
\text { integrity }\end{array}$ & Marginal & Rarely & $\mathrm{L}_{\mathrm{g}}$ & Corruption \\
\hline \multirow{3}{*}{ Material interest } & Moderate & Rarely & $\mathrm{L}_{\mathrm{g}}$ & $\begin{array}{l}\text { Violence (i.e., assault causing } \\
\text { permanent damages) }\end{array}$ \\
\hline & Marginal & Rarely & $\mathrm{L}_{\mathrm{g}}$ & $\begin{array}{l}\text { Violence (i.e., medical treatment of } \\
\text { petty assaults) }\end{array}$ \\
\hline & Marginal & Rarely & $\mathrm{L}_{\mathrm{g}}$ & Corruption \\
\hline \multirow[t]{2}{*}{ Reputation } & Marginal & Always & $M_{g}$ & $\begin{array}{l}\text { All criminal activities (non-enforcement } \\
\text { effect) }\end{array}$ \\
\hline & Marginal & Rarely & $\underline{L_{g}}$ & Corruption \\
\hline
\end{tabular}

*Estimates exclude harms associated with cannabis distribution and use.

** Overall incidence, accounting for incidence of activities and of harms in relation to activities. 


\section{Working through harm assessment process}

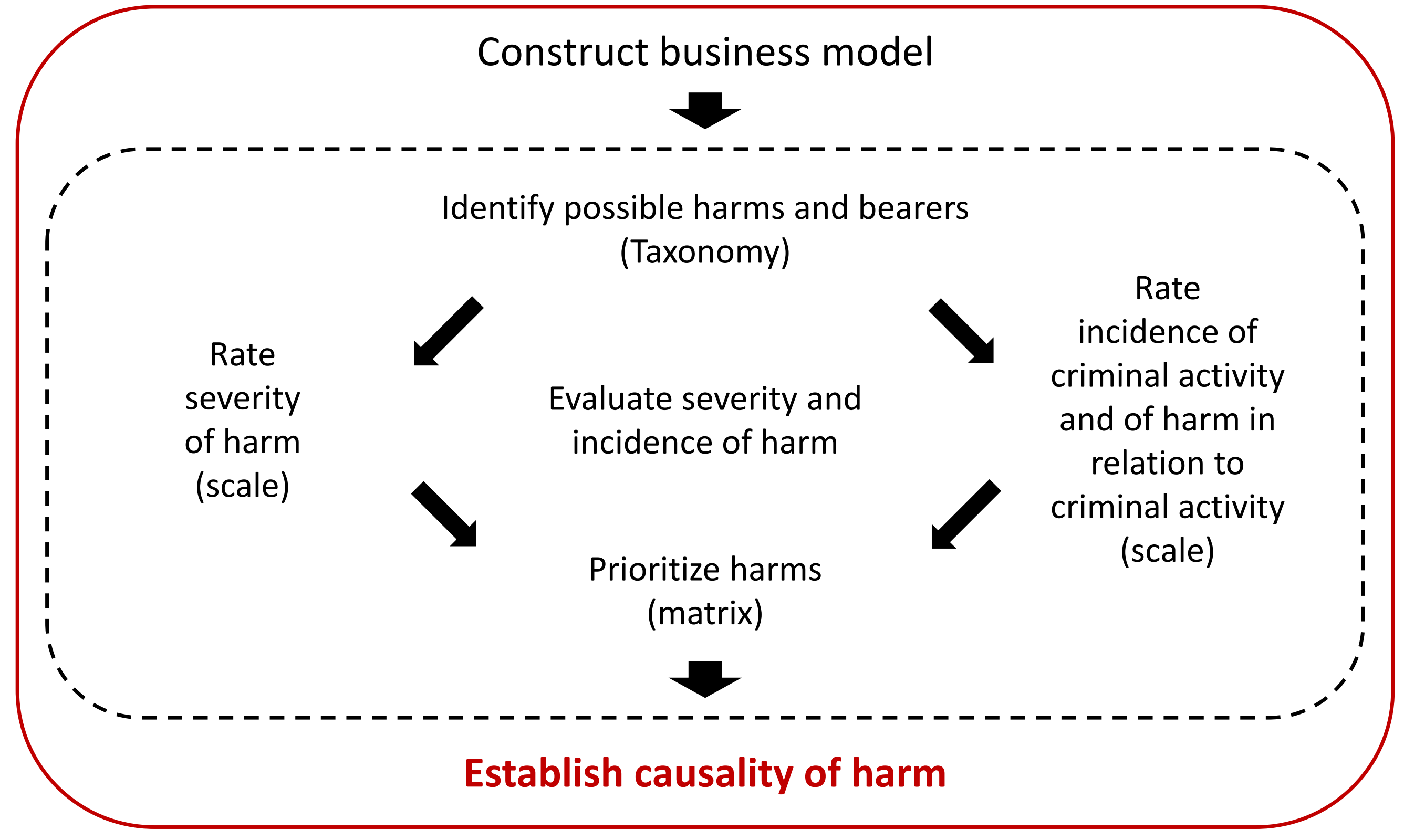




\section{Policy plays substantial role in non-use- related harms, other harms TBD}

- As with cocaine trafficking, most non-use-related harms arise from illegal status and specific enforcement practices

- Harms associated with growing and harvesting

- Harms associated with violence, corruption and money laundering

- Use-related harms to-be-determined

- Some harms arise from properties of drug, but policy, modes of enforcement, etc. also play part 


\section{Outline}

- Project aims, methods and samples

- The harm assessment framework (Greenfield \& Paoli, 2013)

- Identifying the harms associated with cannabis cultivation and its accompanying activities

- Assessing the severity and incidence of the harms and establishing their causes

$>$ Concluding remarks 


\section{Concluding remarks}

- Cannabis production causes more harms to Belgium than cocaine trafficking

- Slightly more harm from violence, harm to individuals' material interest from growing and harm to private-sector entities from money laundering

- Illegal status of cannabis and enforcement practices are themselves cause of most non-use-related-harms

- Are these harms offset by the use-related harms prevented by prohibition?

- Analysis needs to be completed but non-use-related harms seem to be not uniformly distributed across different types of cultivators

- Large-scale cultivators seem to be largely responsible for them

- Small-scale cultivators (< 20 plants) cause limited harms and can even be said produce "benefits," by subtracting market share to "organized crime" groups

- What's the best policy recipe to minimize all harms? 